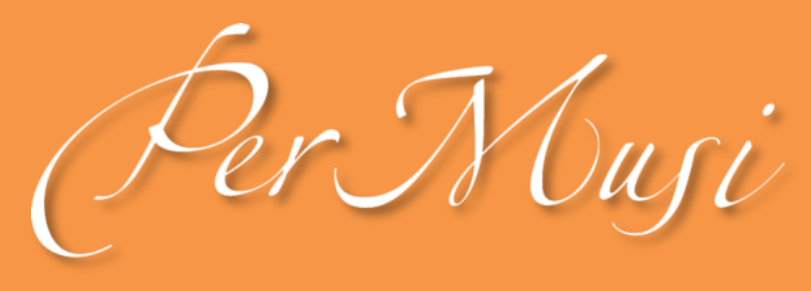

eISSN 2317-6377

\title{
Performance e sentido no DVD da Banda Quilombo do Rio das Rãs
}

\author{
Rita de Cássia Mendes Pereira \\ https://orcid.org/XXXX-XXXX-XXXX-XXXX \\ Universidade Estadual do Sudoeste da Bahia, Programa de Pós-graduação em Letras \\ ricamepe@hotmail.com
}

Elisabete Tâmara Galvão dos Santos

https://orcid.org/0000-0003-1754-9924

Universidade Estadual do Sudoeste da Bahia, Programa de Pós-graduação em Letras

elitagal@outlook.com

SCIENTIFIC ARTICLE

Submitted date: 30 OCT 2021

Final approval date: 28 NOV 2021

Resumo: O texto tem por objeto a relação entre performance e produção de sentidos no espetáculo da Banda Quilombo do Rio das Rãs, realizado em 2009, na cidade de Bom Jesus da Lapa-Ba. A análise foi calcada nas regras da performance (Zumthor 2014), tendo como referência o tempo e o lugar de realização do espetáculo, a finalidade do ato comunicacional, as ações dos músicos e das dançarinas e o perfil do público, nos diferentes tempos de recepção. O protagonista da ação performática é o sujeito quilombola, que fez da música o meio para sair da sua condição habitual, marcada pela exclusão e pelo preconceito. Por outro lado, o trabalho buscou refletir sobre o poder da performance, de modificar o conhecimento que artistas e público têm sobre si mesmo e sobre o outro e, portanto, de atuar sobre a percepção do mundo que mobiliza os sujeitos em seus processos identitários.

Palavras-chave: Performance; Produção de sentidos; Quilombolas; Identidade.

\section{TITLE: PERFORMANCE AND MEANING IN THE QUILOMBO DO RIO DAS RÃS BAND'S DVD}

Abstract: The text object it is the relationship between performance and production of meaning in the performance of Banda Quilombo do Rio das Rãs - held in 2009 - at Bom Jesus da Lapa (state of Bahia, Brazil). The analysis was based on the rules of performance (Zumthor 2014), having as reference time and place of performance, purpose of the communicational act, musicians' actions and audience profile. The protagonist of the performative action it is the quilombola subject, who made Music as a mean to get out of his usual condition, marked by exclusion and prejudice. This work sought to reflect on the power of performance, to modify the knowledge that artists and audience have about themselves and to act on the perception of the world that mobilizes subjects in their identity processes.

Keywords: Performance; Production of meaning; Quilombolas; Identity.

(a) (1) 


\section{Performance e sentido no DVD da Banda Quilombo do Rio das Rãs}

Rita de Cássia Mendes Pereira, Universidade Estadual do Sudoeste da Bahia, ricamepe@hotmail.com Elisabete Tâmara Galvão dos Santos, Universidade Estadual do Sudoeste da Bahia, elitagal@outlook.com

\section{Introdução}

O desenvolvimento e popularização dos recursos digitais de registro e arquivamento de informações está na base do fenômeno contemporâneo de ampliação do universo da comunicação. Lipovetsky e Serroy (2011, 10) propõem abordar a partir do conceito de cultura-mundo esse tempo em que a circulação de imagens e a multiplicação de canais de trocas são viabilizadas pelas tecnologias digitais. Nesse contexto comunicacional, ao qual se pode nomear como cibermundo, as atividades e os objetos compreendidos na ideia de cultura saem do enquadramento do supérfluo, do opcional ou do periférico e tornam-se essenciais à abordagem da sociedade como dos processos de produção de conhecimentos. Por outro lado, artefatos midiáticos de base digital tornaram-se veículos para fluxos ininterruptos de objetos e manifestações culturais, cuja produção e difusão inserem-se em transformações sociais e políticas que envolvem tanto os realizadores como o público. Desde as últimas décadas do século $X X$, as tendências à uniformização e à pasteurização de formas, próprias ao fenômeno da globalização, convivem, contraditoriamente, com a projeção de performances que reforçam processos identitários e viabilizam o reconhecimento e valorização de manifestações culturais antes excluídas do circuito das artes. A ideia de hipercultura ajusta-se, com perfeição, a esse tempo, no qual práticas e dinâmicas convergentes com as aspirações e experiências da massa, projetadas pelas tecnologias digitais de reprodução, passam a ocupar o centro das reflexões em diversos campos do conhecimento. Para Martín-Barbero, esse contexto comunicacional, viabiliza a construção de novos sentidos, torna possível "outro tipo de existência das coisas e outro modo de acesso a elas" (Martín-Barbero 1997, 74).

Schaeber $(1997,147)$, reconhece que a globalização da mídia e da indústria de lazer aponta para um processo de homogeneização das práticas culturais, de conteúdos e performances, mas, ao mesmo tempo, permite a projeção de culturas de base étnica e trocas simbólicas entre povos que comungam de referenciais análogos. É o que ocorre com a juventude negra brasileira, que se abre a formulações identitárias e artísticas dos negros de outras partes do mundo. É imperativo reconhecer o papel dos meios de comunicação e das formas inovadoras de exposição midiática no favorecimento à produção de novos estilos de música capazes de modificar a vida das novas gerações. Munanga e Gomes $(2016,163)$ destacam, como exemplo desse fenômeno, a integração de ritmos e formas de expressão, como o funk e o hip-hop, às expressões musicais e performativas brasileiras, em torno das quais se unem parcelas da juventude negra motivadas pela perspectiva de construção de novos sentidos. 
Em consonância com recentes reflexões sobre cultura, comunicação e transformações sociais, na contemporaneidade, e, em especial, com os estudos voltados às experiências culturais da juventude negra no Brasil, o presente trabalho se dedica à análise da performance dos sujeitos do espetáculo da Banda Quilombo do Rio das Rãs. Gravado ao vivo em 2009, em praça pública, na cidade de Bom Jesus da Lapa-Ba, o vídeo da apresentação foi, posteriormente, prensado em mídia digital e distribuído em escolas e universidades da região Oeste da Bahia. Realizada segundo os pressupostos das regras da performance, conforme proposição de Paul Zumthor (2014, 34), a análise levou em consideração o tempo e o lugar de realização do espetáculo, a finalidade da ação performática e as ações dos sujeitos que atuaram como músicos e dançarinos. Procurou-se perscrutar, também, o perfil do público nos tempos distintos de produção e divulgação do DVD.

A performance tem o poder de modificar o conhecimento que artistas e público têm sobre si mesmos e sobre o outro e, portanto, atua sobre a percepção do mundo que mobiliza sujeitos em seus processos identitários. A ação performática aqui tomada como objeto de investigação projeta como protagonista o sujeito quilombola, representado pelos integrantes da banda. Esse sujeito coletivo aparece, no momento da realização do espetáculo, em posição diferente da sua condição habitual, marcada pela exclusão das condições de acesso à cidadania plena e pelo preconceito. A comunidade rural quilombola, representada pela banda, ocupou a centralidade das atenções diante da sociedade urbana que sempre a manteve à margem e pôde exibir-se em condições de pleno gozo do direito de vivenciar ritmos e danças e de enunciar discursos ancorados em saberes e práticas inerentes ao grupo. A gravação, ao vivo, do espetáculo, assim como a posterior produção e difusão do objeto audiovisual (DVD), indica que "algo se criou, atingiu a plenitude e, assim, ultrapassou o curso comum dos acontecimentos" (Zumthor 2014, 35).

A confecção do objeto de divulgação midiática atendeu ao objetivo de divulgação do espetáculo e, de uma forma mais geral, da expressão artística da comunidade do Quilombo do Rio das Rãs. Mas isso ocorreu cinco anos após a produção, realização e captura do espetáculo em áudio e vídeo. Necessário, portanto, distinguir os contextos nos quais esses processos ocorreram e essencial destacar o papel dos agentes sociais e políticos, internos e externos à comunidade, que tornaram viável tanto o espetáculo como a produção e distribuição do DVD. Uma das chaves explicativas para a presença excepcional da banda quilombola no núcleo urbano do município está na natureza do evento que garantiu essa presença. Trata-se de um evento comemorativo do aniversário da Pastoral da Juventude e do Meio Popular (PJMP), organização ligada a setores progressistas da Igreja Católica. Quanto aos processos posteriores, que permitiram a divulgação do espetáculo em tempos e espaços dos quais é impossível delimitar fronteiras, eles envolvem outros agentes públicos e projetos culturais que confluíram para a realização do objetivo central do idealizador e produtor da banda: a inserção da produção musical quilombola no universo da indústria cultural. O vídeo da Banda Quilombo do Rio das Rãs foi contemplado com recursos públicos do Edital de 2014 do Calendário das Artes, projeto do Governo do Estado da Bahia. As mídias produzidas com o recurso captado foram distribuídas em escolas, bibliotecas e universidades.

A divulgação do espetáculo em outros tempos e espaços além daqueles da produção possibilitou a renovação de sentidos sobre a cultura quilombola, de base territorial rural, à qual se pretendeu, inicialmente, dar visibilidade no momento da performance. Como recurso sonoro e visual, o DVD possibilitou a apresentação, a novos públicos, de um ideal estético e de um conjunto discursivo voltados à valorização da história de negros e negras identificados com as memórias de luta dos quilombos. As tecnologias digitais 
disponíveis à época permitiram a difusão de marcas e simbologias próprias ao grupo e à sua comunidade. Como salientam Lipovetsky e Serroy $(2011,10)$, no mundo globalizado produtos e ações calcados em experiências identitárias ganham materialidade como objetos de consumo e, a partir deles, novos sentidos e estilos são produzidos

Por meio de falas, cantos e danças, os integrantes da banda assumiram publicamente a responsabilidade sobre as escolhas de temas e formas que orientaram a construção de novos modelos de conduta para os jovens da comunidade. Mais do que isso, embora subordinado a determinadas normas socioculturais, o espetáculo se orienta pela perspectiva de mudança, de reconhecimento e valorização da importância dos negros e negras do Brasil, como de sua arte, e difunde o desejo de conquista da cidadania plena para todos que se reconheçam nas histórias, nos ritmos e nos gestos ali evocados. Transpostas para outros lugares que não o locus original de criação (a comunidade rural quilombola), o espetáculo performático mobiliza memórias e afetos e incita a reflexão, primeiramente por parte do público presente ao espetáculo; depois, com a difusão do DVD, por parte dos múltiplos sujeitos que não compartilharam as circunstâncias da realização da performance, mas que por ela foram afetados. Esses novos públicos, adicionados à Banda Quilombo do Rio das Rãs mediante a distribuição da mídia digital, são compostos, sobretudo, de crianças e jovens de algum modo integrados às tecnologias digitais de informação e comunicação, que apontam para a superação de fronteiras de espaço e tempo e para a interação entre as experiências sensoriais provocadas por som e imagem.

O espetáculo cristalizado em mídia digital tem como base a música, linguagem universal que transcende línguas e fronteiras, e integra esse campo mais amplo do que se entende como arte, que viabiliza a aproximação entre os homens e as coisas e a ruptura de muros sociais. Por meio da arte, como salienta Martín-Barbero $(1997,74)$, é possível sentir-se próximo até das coisas mais longínquas e sagradas. Todos esses elementos apontam para as múltiplas possibilidades de recepção e, por conseguinte, de renovação de conteúdo, formas e sentidos da performance por um público cada vez mais amplo e mais distante, fisicamente, dos agentes performáticos.

Para os sujeitos envolvidos na realização da performance, e para aqueles que deram condições de existência ao espetáculo e ao DVD, a produção artística serve à valorização das formas de expressão, como da força e resistência do povo representado pela Banda Quilombo do Rio das Rãs. Mas ela deve servir de estímulo ao autorreconhecimento e à mobilização de um contingente populacional muito maior do que a comunidade rural na qual a banda teve origem. A produção e a difusão da ação performática servem, portanto, aos propósitos de promover a mobilização de capacidades criativas e de desencadear ações sociais e políticas em defesa da ampliação do acesso à educação, à profissionalização, à saúde e ao lazer, enfim, à cidadania da população afrodescendente brasileira.

\section{Espaço e elementos performativos na apresentação da Banda Quilombo do Rio das Rãs}

Como grupo musical performativo, a Banda Quilombo do Rio das Rãs fez a apresentação em praça pública em consonância com os propósitos gerais definidos para o espetáculo, com a natureza do evento que garantiu a sua presença em praça pública e com o horizonte de expectativas em relação ao público. Do ponto 
de vista da ocupação do espaço, o grupo esteve limitado ao padrão que orientava as apresentações musicais na época da produção do espetáculo. O compositor/cantor e os músicos (instrumentistas e vocal de apoio) ocuparam a área central de um palco retangular, de estrutura metálica, medindo 7 x 4 metros, posicionado a dois metros de altura em relação ao chão. Os membros da banda permaneceram em posições mais ou menos fixas durante toda a apresentação, o que sugere a existência de marcadores de palco e a realização de pelo menos um ensaio no local da apresentação.

No fundo do palco, havia uma estrutura metálica coberta por uma lona branca, estendida verticalmente, na qual destacava-se a presença de adereços artesanais, feitos com galhos retorcidos, com formato semelhante a mandalas. Havia, na parte frontal superior do palco, uma faixa comemorativa dos 30 anos da Pastoral da Juventude e do Meio Popular (PMJP). Na parte frontal inferior, encontravam-se expostas faixas de tecido em cores: do lado esquerdo, faixas nas cores amarela, preta e verde; do lado direito, faixas amarelas, vermelhas e azuis, cores comumente associadas à simbologia afro-brasileira. A superfície sobre a qual atuavam os músicos encontrava-se coberta por uma lona plástica branca, semelhante à que recobria o fundo do palco. O branco dava visibilidade aos elementos cênicos e, também, às dançarinas, que, com indumentárias estampadas em cores semelhantes às das faixas, performavam à frente do palco, ao nível do chão.

O grupo contava com nove instrumentos de percussão: timbales, repiques e tambores, tocados por jovens músicos, que tateavam baquetas ou batiam nos tambores com as mãos. Pintados de verde, amarelo e vermelho, os instrumentos definiam o ritmo das músicas e reforçavam a vinculação do grupo com os particularismos étnico-culturais evocados nas canções e no cenário. Há que se destacar, também, a presença de um instrumento de corda, o violão, tocado pelo vocalista, compositor e líder da banda: Moisés Cândido da Silva, conhecido como Professor Zezinho.

Os recursos de iluminação e sonorização eram compostos por grandes caixas de som, situadas dos dois lados do palco, empilhadas próximas a pequenos canhões de luz. Para potencializar os efeitos de luz e som, estavam também ali dispostos dois equipamentos de saída de gás-fumaça. A estrutura ofertada pela organização do evento era, seguramente, muito distinta das condições de produção vivenciadas pela banda na realidade socioespacial do quilombo.

A convite da organização do evento, o espetáculo deu materialidade, no espaço urbano do município de Bom Jesus da Lapa, ao desejo de reconhecimento do trabalho desenvolvido na comunidade rural. Mas, em última instância, permitiu a difusão de experiências mais amplas do universo afro-brasileiro e, mais especificamente, quilombola. A gravação ao vivo era, para os seus idealizadores, uma possibilidade de inserção do grupo em uma nova realidade, da reprodução e difusão de conteúdos e formas. Por outro lado, o sonho de integração ao mercado da música tornava premente a adoção de novos modos de fazer. Como salientam Lipovetsky e Serroy $(2011,17)$, em tempos de cultura-mundo, experiências socioculturais de grupos tradicionais submetem-se aos padrões tecnológicos disponíveis e às exigências de bom desempenho e eficiência próprios à cultura de mercado. Mas, como destacam os mesmos autores, globalmente, qualquer perspectiva de homogeneização derivada dessa submissão é confrontada pela problemática das identidades coletivas, das "raízes", do patrimônio, das línguas nacionais, do religioso e dos sentidos que alimentam o mundo da hipercultura. 
Na apresentação da Banda Quilombo do Rio das Rãs, os elementos comunicativos não-verbais, dispostos na organização do palco, como no figurino dos músicos e dançarinas, codificam referências e aspectos culturais próprios à comunidade de origem, mas, de forma integrada, aludem às raízes e experiências identitárias da população negra no Brasil. Todas essas referências são reforçadas pela performance. De acordo com Zumthor (2014, 34), performance indica competência, um saber-ser que implica e comanda certa presença e conduta inscritas em coordenadas espaços-temporais e fisiopsíquicas concretas, numa ordem de valores encarnada em um corpo vivo.

Os corpos vivos presentes no espetáculo da Banda Quilombo do Rio das Rãs apontam para o anseio de ressignificação dos corpos negros. Conforme afirma Gomes $(2017,79)$, as marcas históricas presentes nesses corpos os direcionam a assumir, por meio da performance, competências adquiridas em uma história de luta e resistência. Essa história renova-se, cotidianamente, na tensão vivenciada por negros e negras, espremidos entre as exigências de adaptar-se e a necessidade de superar o pensamento racista, que toma seus corpos por exóticos, eróticos ou violentos. É, pois, como expressão do embate com o racismo e a exclusão, que a Banda Quilombo do Rio das Rãs exibe coreografias destinadas a enaltecer valores culturais e sociais de base identitária.

Assim como as danças e outros movimentos corporais, a performance da banda engloba um modo próprio de entoar os versos das canções, o ritmo, o cenário, as roupas, o modo peculiar de apresentação e manuseio dos instrumentos musicais. Discurso e performance se conjugam para divertir, mas também para apresentar corpos negros, não como força de trabalho e peças (objetificadas). Eles são, naquele contexto, corpos políticos, marcados por lutas, processos identitários e saberes emancipatórios, no sentido proposto por Gomes $(2017,98)$. As simbologias negras estão presentes nos cabelos trançados, nas batas estampadas, nas cores das roupas usadas por músicos e dançarinas. Para os membros do grupo, todos esses elementos estão assentados em referências ancestrais. $O$ espetáculo atualiza essas referências diante do público ao negar os estereótipos racistas e confrontar, por meio da ressignificação da história viva e vivenciada pelos negros, o cotidiano marcado pela exclusão.

É possível apontar para a similaridade entre as músicas executadas pela banda e o que se convencionou chamar de samba-reggae. Em seus aspectos mais gerais - a temática das canções e a batida dos instrumentos percussivos - o trabalho da banda converge com as observações de Schaeber $(1997,146-147)$ sobre as características da música negra baiana, em especial das músicas produzidas pelos blocos afro de sambareggae, que associam as síncopes típicas do reggae com os tambores de som mais grave, tocados lentamente. Schaeber $(1997,145)$, em suas considerações sobre a formação da identidade negra no Brasil, destaca a importância do movimento cultural protagonizado pelos blocos afro de Salvador. A estética dos seus integrantes, de acordo com o autor, tematiza a herança africana. As músicas, cantadas e tocadas no ritmo marcado pela percussão, reportam à capoeira angola e trazem referências aos movimentos políticos de libertação panafricana e ao movimento negro norte-americano. Mas, para além das experiências performativas, as ações desenvolvidas por esses blocos englobam atividades educativas que conferem aos negros da periferia de Salvador a oportunidade de aprender e desenvolver novas competências. Além disso, ações mais amplas, do ponto de vista organizativo, são assumidas pelas lideranças no intuito de criar as condições de realização dos desfiles. A escolha e preparação de instrumentistas, cantores, apoio vocal, repertório, corpo de dança, figurino, precedem os momentos de exibição pública, no carnaval, e duram todo o ano. Referindo-se à importância da música negra no enfrentamento de problemas que atingem o sujeito 
social negro no Brasil. Schaeber $(1997,151)$ ressalta o trabalho da Banda Olodum, que se tornou referência na luta política contra o racismo. Os caminhos trilhados pelo Olodum, com projetos sociais de cunho educativo e enunciação de discursos de resistência, materializados em canções, despertam, ainda hoje, em uma parcela dos jovens de Salvador, o interesse pela história dos povos africanos e dos negros no Brasil. Arte e educação são, nos projetos do grupo, a base para o autorreconhecimento, a construção da identidade, a socialização e a luta por melhoria das condições sociais desses jovens. Na capital da Bahia, nas últimas décadas do século $X X$, outros blocos afro somaram-se a esse propósito, de sustentação da autoestima de negros e negras, em contextos marcados pelo recrudescimento de preconceitos e exclusão, mas, também, pela renovação das formas de enfrentamento ao racismo.

O projeto da Banda Quilombo do Rio das Rãs integra-se a essa mesma perspectiva, de favorecer o autorreconhecimento e a melhoria das condições de vida das crianças e jovens negros, mediante a realização de ações nos campos da educação e da arte. Professor Zezinho expõe, em depoimento que integra o DVD da banda, gravado em 2014, a sua trajetória, desde a criação do grupo de capoeira para crianças da comunidade até a sua atuação como compositor e líder da banda:

[...] da capoeira a gente se estendeu fazendo o teatro, colocando as crianças para aprender música [...] levando as crianças pra a escola, incentivando as crianças diretamente pra escola, aonde graças a Deus, em 2002, nós conseguimos trazer 16 alunos que não tinha formado dentro do quilombo do Rio das Rãs, conseguimos formar 16 alunos no Ensino Médio, e daí prá frente se estendeu também com os alunos fazendo já faculdade também. E aí o quê que aconteceu, no teatro necessitava de músicas que é...tivesse assim mais ao que com os trabalho afro que nós fazíamos e, às vezes, eu pegava músicas de Gil, de... esse menino, de... Edson Gomes e outras pessoas e tal, mas foi necessário que eu começasse a compor, e aí então foi quando eu comecei a compor minhas próprias músicas, e uma delas a primeira música foi a Ganga Zumba, né, que é as minhas tranças, né, "vocês pagam pau pela minhas tranças". Essa música ela chama Identidade Física, essa música eu escrevi é... prá que as pessoas entendessem como era resgate dos negros quando estavam escravizados, na época de Ganga Zumba e Zumbi, [...] prá poder, por exemplo, tirar dos canaviais da mão das pessoas que escravizavam [...]" (Transcrição de depoimento do Professor Zezinho que integra o DVD da Banda Quilombo do Rio das Rãs, 2009, 3'32" a 6'23")

Por outro lado, a conhecimento e assimilação de ritmos do samba-reggae concede ao líder da Banda Quilombo do Rio das Rãs o papel de mediador entre a expressão artística da comunidade rural quilombola e um movimento cultural mais amplo, ancorado em ritmos, símbolos e outros aspectos culturais associados às experiências dos africanos da diáspora. Como pode ser observado no registro audiovisual do espetáculo, esses ritmos possibilitam a sintonia com parte significativa dos espectadores, que acompanham, com os seus próprios corpos, o som dos tambores e a cadência dos movimentos corporais de músicos e dançarinas. Como avalia Zumthor (2014, 41-42), o ritmo de uma canção implica - juntamente com sua melodia, linguagem e com os gestos que o acompanham - pulsações comuns entre quem produz, quem aprecia e, mesmo, os outros que transitam em volta do espetáculo. O ritmo dilui a divisão entre plateia e palco porque produz uma experiência única. Schaeber $(1997,146)$ indica, por sua vez, que "música e dança refletem uma realidade social e oferecem os instrumentos com que os indivíduos estão continuamente negociando e 
renegociando hierarquias e espaços entre eles". Efetivamente, no ritmo marcado pelos instrumentos e expresso nos movimentos dos corpos dos múltiplos sujeitos da performance, define-se, no tempo e espaço do espetáculo, uma escala hierárquica, na qual os integrantes da banda ocupam o patamar mais alto. No plano intermediário, à frente do palco, as dançarinas atuam como condutoras, orientando os movimentos corporais das pessoas da plateia. Essa hierarquia contraria a ordem social que, fora da performance, coloca os negros quilombolas em condições de subalternidade e exclusão.

Realizada em um determinado contexto cultural e situacional, conforme avalia Zumthor (2014, 35), a performance emerge do modo de ser e ver o mundo atrelado a tradições culturais cuja essencialidade se mostra em cada detalhe do espetáculo. A apresentação da Banda Quilombo do Rio das Rãs foi inserida na programação do 3을 Congresso Nacional da Pastoral da Juventude e do Meio Popular como atividade cultural, supostamente voltada ao entretenimento. Considerando-se, entretanto, a natureza do evento e os agentes sociais e políticos envolvidos na sua realização, é possível vislumbrar uma perspectiva de integração social dos jovens quilombolas e de valoração positiva de suas experiências culturais, dos seus modos peculiares de ser e ver o mundo e de suas tradições.

A Pastoral da Juventude e do Meio Popular (PJMP), aludida na faixa do evento que abrigou o espetáculo da banda, foi criada em julho de 1978, em Recife-Pe, e abrigou, em seus quadros, jovens do meio popular e remanescentes da antiga Juventude Operária Católica (JOC), que havia sido objeto de perseguição pelo governo ditatorial-militar, instalado com o Golpe de 1964. Oliveira e Paiva situam o nascimento da PJMP no contexto de recrudescimento das lutas sociais e políticas e de reorganização interna da Igreja Católica na América Latina, no final da década de 70 e início da década de 80 do século XX:

O contexto inspirador para o nascimento da PJMP foi, por um lado, a realidade concreta dos jovens e o ressurgimento das lutas sociais e políticas que acontecia no Brasil, e, por outro, o contexto eclesial da Igreja Latino-Americana e do Regional NE II, que, sob a orientação e o pastoreio de Dom Hélder Câmara, construía um modelo de organização pastoral no qual o pobre era sujeito histórico de libertação. A PJMP nasceu bebendo no seio desta Igreja e assumiu a visão de que a transformação da realidade é obra dos oprimidos e de todas as pessoas de boa vontade que se comprometem com as lutas de libertação (Oliveira e Paiva s.d.)

A Igreja Católica teve atuação marcante em diversos outros momentos da história do povo do Rio das Rãs. Na década de 90 do século XX, por exemplo, concedeu suporte às famílias durante os conflitos pela posse da terra. Em 2009, com a integração do grupo cultural quilombola à programação do 3 o Congresso Nacional da PJMP, ofertou ao idealizador e aos jovens da banda a oportunidade de falar da história da comunidade por meio da arte. A inciativa indica uma percepção particular, sustentada pelo movimento pastoral, sobre o papel da juventude nas transformações sociais, e se insere na lógica dos movimentos sociais contemporâneos, que passam a contemplar plataformas identitárias, o princípio da diversidade e a demanda por universalização dos Direitos Humanos.

Assim, com a mediação da Igreja Católica, em seu segmento progressista representado pelo movimento pastoral, no ano de 2009, depois de séculos de exclusão e preconceito, os quilombolas de uma pequena comunidade rural do município de Bom Jesus da Lapa foram convidados a ocupar, em condições de 
centralidade, o território da praça pública da cidade-sede. Durante o espetáculo, os jovens quilombolas das Rãs assumiram o protagonismo na luta de resistência e por direitos, espelhados na história e memória da sua comunidade e nas referências aos ancestrais africanos e nascidos no Brasil. A corporeidade da negra e do negro que protagonizam a experiência performática reflete uma trajetória marcada por solidariedades e desejos de liberdade.

A canção de abertura do DVD da Banda Quilombo do Rio das Rãs, intitulada "Nossa história é exótica para vocês", evoca a força, a sabedoria e a ginga dos negros. O discurso é dirigido aos brancos que desconhecem as histórias dos negros e desprezam os seus saberes ancestrais:

Vocês não aceitam nossa cor

Somos origem do negro banto, gege ou nagô

A nossa história é exótica para vocês

Angola, lorubá e os 'sudanês'

Nosso rei, Ganga Zumba, montado no seu cavalo

Vendo o seu povo escravizado ele sorria

Transmitindo a esperança e alegria

O negro é a ciência africana

Sabedoria, conhecimento da baiana

Nossos cabelos trançados rastafári

A nossa ginga mostra nossa identidade

Nosso batuque, nossa música, nossas danças

Vocês querem nos imitar

Sei que vocês "pagam pau" pelas nossas tranças (três repetições)

Mesmo vocês sorrindo dos nossos cabelos

Aumenta nossas esperanças

Mesmo vocês sorrindo dos nossos sorrisos

Aumenta nossas esperanças

O público, majoritariamente composto por jovens, lotou a praça para receber os quilombolas e dançou ao ritmo dos instrumentos, acompanhou os movimentos propostos pelas dançarinas e cantou, juntamente com o vocalista, trechos de canções com referências positivas à África e aos africanos da Diáspora.

Como destaca Zumthor $(2014,42)$, a performance não somente se liga ao corpo, mas, também, ao espaço por ele ocupado. O espaço da apresentação da Banda Quilombo do Rio das Rãs se prolonga mediante o uso de caixas de som amplificadoras e de um telão que, situado ao lado do palco, expandia as condições de visualização dos músicos e das dançarinas e projetava imagens do público mobilizado. No espaço da praça, é simbólico o papel desempenhado pelas dançarinas, que ora se perfilam à frente do palco, de costas para a banda, de frente para a plateia, ora se aproximam do público, apresentando-se de frente para o palco. Transitando entre as duas formas, elas sugerem integração, reconhecimento, aceitação, valorização do outro e renovam as esperanças consignadas no lema do congresso que abrigou a apresentação: "Em nossas mãos um sonho em mutirão". 
O público responde às provocações dos ocupantes do palco mediante a mobilização dos seus próprios conhecimentos e toma decisões imediatas, que acabam por interferir na performance. Na situação performancial, a operação cognitiva aproxima aquele que contempla daquele que desempenha o ato performativo - no caso, o sujeito quilombola -, materializado nos corpos negros de músicos e dançarinas. Entendido por Zumthor $(2014,44)$ como lugar cênico e próprio da manifestação das intenções do autor, o espaço da performance prolonga-se para além do palco e da praça. No caso em análise, outros espaços devem ser considerados, como a cidade e a região, lugares nos quais se renova o processo de apropriação dos discursos enunciados e das formas culturais que lhes dão existência.

\section{0 corpo negro em performatividade}

Para Zumthor $(2014,41)$, na performance há sempre um elemento irredutível, materializado pela presença de um corpo. Na apresentação da Banda Quilombo do Rio das Rãs, a corporeidade negra é reafirmada e ganha lugar de destaque. Ela é o símbolo vivo da luta de resistência, com a qual ficou marcada a história de negros e negros no Brasil. Munanga e Gomes $(2016,152)$ observam que aos africanos escravizados e seus descendentes brasileiros nascidos sob o regime da escravidão era negado o domínio sobre o próprio corpo. Corpos obrigados a trabalhar no ritmo ditado pelos senhores, na produção rural, na mineração, na manutenção e cuidados na casa senhorial, como em outras atividades determinadas pelas necessidades da classe dominante. Além de submetidos ao trabalho braçal, homens e mulheres escravizadas tinham seus corpos violentados, eram obrigados a alimentar os filhos da casa grande e a atender desejos e fantasias sexuais dos brancos. Para Gomes $(2017,79)$, essas condições conduziram, historicamente, à condenação do corpo negro, à sua invisibilidade e à negação de saberes e valores positivos a ele associados. Mesmo com a suposta universalização da educação, que viabilizou a presença, ainda que em condições de desigualdade, de negros em ambientes escolares, os corpos negros continuaram sendo tratados como exóticos e suas manifestações foram associadas a temas relacionados ao "folclore", compreendido como uma cultura de segunda categoria.

Como contraponto a esse processo de exclusão e aos preconceitos dele derivados, desde o tempo em que africanos e afrodescendentes estavam submetidos à escravização, como afirmam Munanga e Gomes (2016, 152), o corpo negro ganhou importância como instrumento de afirmação de valores socioculturais e como agente emancipador. A performance corporal de natureza emancipatória estava presente em ações de combate, como em ritos religiosos de matriz africana e em outras expressões culturais indicativas de sociabilidade entre os negros e de processos de construção identitária entre descendentes de africanos. A abolição formal da escravidão não significou, para a maioria dos negros do Brasil, a chegada de um tempo de paz e conquista de melhores condições de vida. Pelo contrário, em muitos aspectos, preservou e aprofundou as desigualdades sociais e raciais e impôs a necessidade de renovação das lutas de resistência, por inclusão e por terra de trabalho. Munanga e $\operatorname{Gomes}(2016,107)$ lembram como a desigualdade étnicosocial, reafirmada no pós-abolição, é ainda mais cruel com as mulheres, submetidas às opressões patriarcais.

É para os negros e negras, portanto, fortemente marcados pelas memórias de sofrimento e de luta de seus ancestrais, que falam os corpos dos integrantes da Banda Quilombo do Rio das Rãs. As imagens do espetáculo, registradas em áudio e vídeo, revelam a predominância de jovens negros na plateia. Gomes $(2017,75)$ avalia que o olhar dos jovens negros na atualidade é muito mais firme e afirmativo do que o olhar 
da geração que os antecedeu. Muitos encaram o "outro", discutem questões fundamentais para o bem-viver de suas coletividades e posicionam-se sobre questões raciais. Além disso, ainda de acordo com Gomes (2017, 75), a partir dos anos 2000 ocorreu uma politização e valoração positiva da estética negra. O corpo negro passa a ocupar, aos poucos, o foco de estratégias de mercado, conquista espaços na mídia, em espaços acadêmicos, sobretudo em núcleos e associação de pesquisadores negros, e em instâncias de gestão estatal. Trata-se de um movimento de ressignificação dos corpos negros, com nuances de acordo com a região, com os embates e acomodações entre forças políticas e econômicas e com a própria capacidade organizativa dos movimentos de resistência negra. As políticas de ações afirmativas, sobretudo aquelas implantadas e potencializadas entre 2003 e 2016, durante os governos Lula-Dilma, impactaram sobre as relações de negros e as negras com os seus próprios corpos e demandaram um novo olhar da sociedade brasileira sobre os corpos negros. Como destaca Gomes (2017, 75-76), essas políticas contribuíram para a configuração de um novo perfil de juventude negra, ciosa de ocupar lugares sociais que antes thes eram negados.

Desde o final do século XX, as mulheres negras, em especial, conquistaram autonomia e independência, ao projetarem-se no espaço público como protagonistas de suas próprias lutas, com apoio ou não de políticas públicas. Sua atuação nas organizações e nos movimentos de resistência negra foram ressaltadas por Munanga e Gomes $(2016,133)$. Os seus avanços conduzem à interconexão com paradigmas e plataformas de luta dos movimentos feministas e impulsionam à definição do feminismo negro como um novo campo da práxis social transformadora na contemporaneidade. Gomes $(2017,73)$ destaca a atuação de ativistas negras na difusão de novos saberes e discursos políticos, identitários e estético-corpóreos. Essas ativistas interagem com o Movimento Negro, questionando o machismo, desafiando os homens a mudar suas atitudes em relação às mulheres, seja no plano do público, seja no plano das relações pessoais. Elas denunciam a violência cotidiana contra as mulheres nos espaços sociais, dentro dos lares, no emprego, nos sindicatos e nos partidos. Suas práticas visam a construção de um novo modelo de sociedade, marcado por relações de igualdade de homens e mulheres negros e que abarque pessoas de diferentes condições sociais e étnicas.

É na esteira dessas transformações que ocorre a atuação performática das jovens moças quilombolas durante a apresentação da Banda Quilombo do Rio das Rãs. No espetáculo, a projeção, em primeiro plano, de mulheres negras é encenada, sobretudo, pelas dançarinas. A análise da performance lança luzes sobre facetas da experiência feminina na comunidade e fora dela. A princípio, as danças executadas à frente do palco parecem apontar para uma memória corporal acumulada no curso de vida de cada uma daquelas jovens, mas também de outras mulheres que as antecederam. Para Zumthor $(2014,79)$, as lembranças corporais que se acumulam ao longo da vida produzem um conhecimento virtual, que interfere na percepção do real. Nessa perspectiva, a performance corporal das bailarinas, integradas ao tempo e ao lugar, orientadas por uma finalidade e ressaltada pelo figurino, revelam marcas ancestrais e modificam a percepção pessoal e do outro sobre as violências enfrentadas pelas mulheres negras e sobre as lutas e conquistas de seus antepassados.

Na realidade, como destacam Munanga e Gomes $(2016,133)$, a despeito das transformações das condições de vida e da ampliação do papel social das mulheres, a mulher negra continua vivendo uma situação marcada pela dupla discriminação, gerada pelo machismo e pelo racismo. Em sua maioria, essas mulheres são responsáveis por cuidar de suas casas, dos próprios filhos, e, muitas vezes, das casas e dos filhos de outras mulheres. Essa realidade afeta, de forma particular, as condições de existência das mulheres do Rio das Rãs, como salienta Oliveira Jr. $(1996,214)$, em seus estudos sobre a organização social inicial das famílias da 
comunidade. Os papéis exercidos pela grande maioria das mulheres, no seio da comunidade, envolvem, além do trabalho doméstico, a organização e realização de práticas religiosas e a consecução de trabalhos manuais, especialmente aqueles voltados para a produção de vestuário. Para as mulheres do Rio das Rãs, a oficialização do direito à terra implicou em mudanças na percepção do próprio corpo e de seus papéis. $\mathrm{Na}$ história mais recente da comunidade, sem desvencilhar-se das obrigações com o cuidado da casa e dos filhos, algumas mulheres passaram a atuar como educadoras em escolas municipais da localidade. Além disso, como destaca Dutra $(2007,68)$, apesar da forte predominância das relações patriarcais, ocorreu o crescimento da participação feminina nas discussões coletivas e na direção da Cooperativa Agropastoril do Quilombo do Rio das Rãs. Elas atuam, sobretudo, na organização de grupos de mulheres dedicadas aos trabalhos artesanais, ao cultivo de hortaliças e ao trabalho com corte e costura.

Para Gomes $(2017,97)$, corpos negros emancipados se distinguem e se afirmam no espaço público como expressão da liberdade. Nesse sentido, a performance das mulheres que atuam na Banda Quilombo do Rio das Rãs, longe de reforçar a exotização e a folclorização dos corpos negros, expressam emancipação e confiança. A presença dessas mulheres, ainda que em papéis secundários, aponta para uma racionalidade estético-expressiva. $\mathrm{O}$ canto e a dança enunciam saberes, formas de sentir o mundo e formas de viver o corpo no mundo. As habilidades demonstradas ao dançar e cantar (há uma mulher no grupo vocal de apoio) indica a incorporação desses saberes nos processos identitários que envolvem mulheres negras. A música e a dança são campos nos quais essas mulheres podem expressar a abrangência desses saberes em torno de questões sociais múltiplas. Ritmo, letra, sons e performance corporal servem ao entretenimento e à ludicidade, mas são, também, indicativos de representatividade e engajamento.

As dançarinas que acompanham a Banda Quilombo do Rio das Rãs manifestam o sentimento que envolve a parcela da juventude negra, em sua maioria periférica, que ostenta o orgulho de suas raízes ancestrais por meio de ritmos, cantos e danças. O corpo, manifestamente livre, que balança ao ritmo da voz e da percussão, coloca em cena um novo olhar sobre o mundo e propõe uma nova forma de participação. Os passos sincronizados remetem ao samba de roda e ao samba-reggae, evocados como símbolos da identidade negra. Há que se ressaltar a diferença entre os movimentos das dançarinas do Rio das Rãs e as danças executadas nos blocos afro de Salvador, onde a forte influência das religiões afro-brasileiras, a exemplo do candomblé, se faz presente na linguagem corporal, nas roupas e nos penteados. Em comum, a exposição dos corpos negros, que se colocam à mostra e repercutem uma estética carregada de elementos simbólicos e identitários.

Historicamente, a invisibilidade, espontânea ou involuntária, dos negros escravizados no Brasil esteve incorporada às estratégias de resistência. Carvalho $(1996,46-47)$ avalia que a sobrevivência de comunidades negras no Brasil passava, muitas vezes, pela ausência total de comunicação e trocas com a sociedade dos brancos. Tornar-se invisível, simbólica e socialmente, sair do foco, demandava, entretanto, a criação de formas de organização e subsistência amparadas em tradições. A experiência coletiva de autoregulação e emancipação da comunidade negra, enquanto corpo social, orienta a experiência individual e coletiva do autorreconhecimento identitário, como explica Gomes em texto escrito em primeira pessoa, endereçado a outras pessoas negras:

O corpo negro não se separa do sujeito. A discussão sobre regulação e emancipação do corpo negro diz respeito a processos, vivências e saberes produzidos coletivamente. Isso 
não significa que estamos descartando o negro enquanto identidade pessoal, subjetividade e individualidade. Há aqui o entendimento de que assim como "somos um corpo no mundo", somos sujeitos históricos e corpóreos no mundo. A identidade se constrói de forma coletiva, por mais que se anuncie individual. (Gomes 2017, 94)

É o que se entrevê na canção "Eu sou negro", que integra o DVD da Banda Quilombo do Rio das Rãs. O discurso, enunciado em primeira pessoa, indica autoaceitação e conclama ao reconhecimento do papel dos povos vindos da África ("raça negra, índia, sela lá quem for"), na edificação da riqueza do Brasil:

Eu sou negro, Eu sou negro, Eu sou negro

Eu não me escondo, tira a minha foto

Eu sou negro, minha pele é escura

A semente genética fez essa mistura

Eu sou negro porque também sou gente

Eu sou negro pela minha cultura

Vindo da África dos meus pertences

Raça negra, índia seja lá quem for

O importante é que me valorizo

E não tenho vergonha de ser o que sou (Repete)

A nossa história é bela de se ver

E é bem facinho de se aprender

É que na verdade muitos tenham medo

Do que de repente venha acontecer

Pois a riqueza do nosso país Brasil

Só Deus saiba a quem merecer

A contribuição do nosso povo negro e índio

Foi quem fez nosso Brasil crescer

A proposição do autor ganha abrangência nas performances coletivas que mobilizam corpos negros capazes de renovar e dar materialidade a saberes, tradições, símbolos. As experiências sensoriais motivadas por essas performances criam conexões entre o mundo e o universo íntimo dos indivíduos. Zumthor $(2014,84)$ salienta a importância da audição, que oportuniza uma presença não somente espacial, mas interior, peculiar. É por meio da audição que o corpo promove uma autocomunicação, na medida em que revela o sujeito para si mesmo e, de uma maneira diferente, para o outro. Deste modo, na apresentação da Banda Quilombo do Rio das Rãs, os agentes da performance, como o público que dela participa, reconstroem em suas consciências, por meio das músicas que ouvem e cantam, saberes sobre a história do povo negro.

Os saberes são mobilizados e se reproduzem, durante o espetáculo, mediante a união entre discurso, música e movimento. Tanto como a audição, a visão é importante para os que dele participam porque permite captar os limites e os elementos constituintes do espaço partilhado, ainda que momentaneamente. Uma vez 
capturado pelas câmaras e armazenado em mídia, esse espaço é reapropriado por uma nova audiência, em uma experiência real e tardia, que pode ou não ser conquistada para o projeto de transformação proposto pelas letras, pelos sons e movimentos corporais. Assim, passado, presente e futuro se entrecruzam a todo momento, desde a idealização da banda, passando pela realização do espetáculo, até a difusão do DVD em meio a uma plateia cada vez mais difícil de precisar a natureza e a abrangência.

\section{Voz, performance e subversão}

Zumthor (2014, 81-82) destaca a importância da ação vocal para que as palavras ganhem força e sejam verdadeiramente expressivas, fundamentais na formação dos efeitos de sentido. Na enunciação, as vozes extrapolam os limites do corpo ao serem escutadas pelo outro. Os corpos que as vocalizam são transportados pelos versos das canções, por exemplo. As vozes e corpos que se expressam por meio da Banda Quilombo do Rio das Rãs não podem ser, nem no aspecto performativo, tampouco no discursivo, dissociadas da história do africano escravizado no Brasil e da história e memória dos negros e negras que, desde o período de dominação colonial até o presente, se mantêm em luta contra as desigualdades, por inclusão e por direito à cidadania plena.

No espetáculo, as vozes encarregadas de enunciar as histórias de negros e renovar o sentido da luta são o vocalista principal, Professor Zezinho, que ocupa a parte central da frente do palco, e o trio vocal de apoio, cujas palavras sonoras reverberam entre os demais membros da banda e no meio do público. Os componentes do trio vocal de apoio à voz principal ocupam a lateral esquerda do palco. Vestidos com roupas similares, eles movimentam-se, na maior parte do tempo, em passos sincronizados, e, por vezes, interagem com a plateia. Acompanhadas por movimentos corporais, mais ou menos expressivos, dos sujeitos que as enunciam, as múltiplas vozes que se somam no canto dão efetividade ao efeito visado de ampliar a reflexão e mobilização em torno de pautas identitárias e transformadoras das condições da população negra.

A voz sempre foi uma aliada do povo das Rãs. Ela era a base de transmissão da memória social, de práticas e saberes. No processo que antecedeu a posse da terra, na ausência de documentação formal que explicassem por que, como e em que momentos a comunidade se constituiu em um grupo identificado e identificável, as vozes dos moradores mais velhos foram responsáveis por construir o panorama histórico que poderia vir a justificar e legitimar a presença e permanência no território (Doria e Carvalho 1996, 130). A coleta de relatos orais e a observação de práticas tradicionais viabilizaram o reconhecimento, por parte de pesquisadores e pelo poder judiciário, do processo histórico que levou os primeiros moradores a se instalar na localidade, desde os primeiros movimentos de ocupação e organização e, também, pelos momentos de agudização dos conflitos com proprietários de terra.

Doria e Carvalho $(1996,138-139)$ afirmam que a definição dos traços simbólicos e políticos dos negros das Rãs remonta ao período da conquista da terra quando começaram a se estabelecer a rede de relações comunitárias e de parentesco com a qual os quilombolas puderem enfrentar os fazendeiros os que se diziam donos da terra. A organização comunitária foi a base para o desenvolvimento de formas coletivas de trabalho e de uso do solo e favoreceu o reconhecimento de traços culturais comuns. As vozes se constituíram, desde então, como instrumentos eficazes para demarcar o tempo dos acontecimentos. A plausibilidade aos relatos dos moradores foi aferida, pelos pesquisadores, mediante a observância de 
confluência de informações sobre fatos, datas e personagens. Posteriormente, esses elementos constitutivos da memória social do grupo, documentados e organizados para fundamentar o processo de reconhecimento do direito à terra, retornaram para o grupo, dotados de uma nova dimensão simbólica, que associa passado, presente e futuro.

A voz é recurso de recuperação e construção de tradições, mas pode ser compreendida, também, como instrumento de subversão. A enunciação vocal comporta um movimento de ruptura, como propõe Zumthor $(2014,81)$ : "a voz é uma subversão ou uma ruptura da clausura do corpo. Mas ela atravessa o limite do corpo sem rompê-lo". A voz desaloja o homem do seu corpo, sem perdê-lo como referência para seu pranto, graça e canto. Por outro lado, no canto performático, como no espetáculo da Banda Quilombo do Rio das Rãs, a voz que chega ao público em timbres e entonações é muito mais do que a expressão de sujeitos reduzidos a experiências e desejos particulares. Pelo contrário, a performance vocal é o lugar do triunfo coletivo. Em conjunto, vocalista, trio vocal de apoio e plateia fazem de suas vozes um canal de comunicação, no qual transitam enunciados discursivos, formas e ações decorrentes da recepção coletiva. Vislumbra-se, como propósito, a construção de um efeito unânime, como propõe Zumthor (2014, 56): "Os que cantam em público têm a intenção de provocar um movimento de multidão. Diversos meios retóricos, rítmicos, musicais contribuem para esse efeito unânime".

Aberta a um público diverso e, portanto, a recepções divergentes, o ato performático não necessariamente logra atingir a unanimidade pretendida. No caso específico da Banda Quilombo do Rio das Rãs, é prudente considerar que uma parte do público presente ao espetáculo esteja imbuída de preconceitos e estereótipos racistas, que levam a julgamentos e reações negativas frente à mensagem proposta pelos quilombolas. Mas o que se observa, durante a análise do documento audiovisual que garantiu o registro do espetáculo, é que, naquele contexto específico, naquele congresso, uma parte significativa do público, composta por jovens que acederam ao convite da Pastoral da Juventude, reage positivamente aos discursos enunciados, de intenção educativa e transformadora. As vozes do vocalista e do grupo de apoio vocal, secundadas pelo movimento dos corpos emancipados, criativos e autônomos, apresentam-se como contraponto ao racismo e convidam ao engajamento nas lutas de resistência. Como afirma Gomes $(2017,58)$, o saber, o sábio e a sapiência renovam-se no ato de comunicação oral. Neste caso, a função do locutor é apresentar a vida social quilombola como ela se realiza e situá-la dentro do jogo simbólico de interesses. A voz é, conforme salienta Zumthor (2014, 83), "uma forma arquetípica, ligada para nós ao sentimento de sociabilidade". O ato de vocalizar é indicativo de que não estamos sozinhos, que podemos ser ouvidos; do mesmo modo que, ao ouvir uma voz, temos a certeza de companhia.

Há um longo caminho a percorrer, no sentido da valorização da diversidade étnico-racial como componente de uma suposta cultura nacional e da conquista da cidadania plena para negros e negras no Brasil. Performances artísticas como a da Banda do Quilombo do Rio das Rãs são fundamentais porque viabilizam o reconhecimento dos povos quilombolas como sujeitos dotados de saberes e porque possibilitam a difusão de conhecimentos sobre suas histórias, seus modos de vida e suas expectativas. Quando a esses grupos é permitido falar em primeira pessoa e performatizar sua cultura e quando o registro dessa performance é reproduzido e difundido em espaços formais de educação, lacunas são preenchidas e novos elementos são ofertados para a ressignificação da sua presença e de sua importância na História do Brasil. 
Presente nas escolas, o vídeo da banda pode ser tomado como contraponto aos materiais didáticos que, frequentemente, tendem a reforçar imaginários sociais, que atribuem ao povo negro papeis secundários, que reduzem em importância as manifestações do corpo negro, das vozes negras e da cultura negra. Como salienta Gomes $(2017,95)$, a educação escolar é um dos principais meios de socialização de discursos reguladores sobre o corpo negro, normalmente amparados em imagens e discursos que fortalecem ideais de beleza associados à branquitude. Na escola, como na vida cotidiana, esforços de construção de uma estética negra são objeto de desconstrução sistemática. É contra esse quadro de coisas que se insurgem as intervenções artísticas, poéticas e políticas que associam criatividade e engajamento político, a exemplo do espetáculo da Banda do Quilombo do Rio das Rãs.

O projeto de prensagem e distribuição do DVD da Banda Quilombo do Rio das Rãs, financiado pelo Governo do Estado da Bahia, resultou na inserção, nas escolas e em outros espaços de cultura, de discursos contra o racismo e a exclusão social. Pautados pela necessidade de desvendamento da desigualdade étnico-racial e de afirmação da importância da história e memória de luta do povo negro, esses discursos se renovam no ato de recepção de imagens e sons veiculados pelas mídias digitais. Desde que exibidas e assistidas por jovens escolares e universitários, as mídias mobilizam disposições cognitivas e afetos em relação à história, memória e cultura dos moradores das Rãs, em relação aos corpos negros, marcados por uma trajetória de luta e sofrimento vivenciada no território mais estrito da zona rural de Bom Jesus da Lapa, mas, também, em toda a Bahia e no Brasil.

Os novos públicos colocados diante das canções e das imagens da banda são inseridos na luta simbólica entre as classes e frações de classe (Bourdieu 1989, 12). Essa luta se reproduz no microcosmo que delimita a existência de cada novo sujeito exposto às mensagens da banda, mobilizada em seus esforços de difundir uma peculiar visão de mundo e uma reflexão sobre a sua presença (e do outro) nesse mundo. A perspectiva afirmativa de que os negros, os quilombolas em especial, têm o seu lugar na história, reforça processos de reconhecimento identitário e projeta os seus agentes na cena pública, política, artística e acadêmica. Como propõem Munanga e Gomes (2016, 166), "ao produzir, divulgar e cantar, os jovens tomam consciência de si mesmos, de sua condição e dos elementos integrantes de suas identidades". A difusão dessa produção em espaços públicos, por meio de espetáculos ou de recursos midiáticos, é, pois, essencial à conquista de novos sujeitos para as lutas de resistência e contra a exclusão e a desigualdade. Conquista que se realiza por meio da visualização e da audição do espetáculo, ofertado ao vivo ou mediado por recursos de reprodução. Vozes, ritmos, discursos reverberam na mente de cada um, são apropriados de formas distintas e suscitam tomadas de posição a partir de suas próprias experiências. Como afirma Zumthor $(2014,81)$, escutar outro indivíduo é ouvir, no silêncio de si mesmo, sua voz que vem de outra parte. Por vezes, as vozes dos múltiplos sujeitos se encontram em um único cantar, em uma atmosfera de compartilhamento de leituras do mundo e de desejo.

A música é, no caso em análise, o principal elemento de mediação entre os quilombolas e outros sujeitos sociais, que podem ou não se associar aos propósitos definidos por aqueles que ocupam o palco em condição de centralidade. Por meio dos sujeitos performáticos, o povo das Rãs propõe o reconhecimento de seu lugar na história e na sociedade, afirma a diferença entre o seu próprio lugar e o lugar do outro, reforça a consciência de que é necessário estar em luta permanente contra a desigualdade, a exclusão e a injustiça que afetam os negros no Brasil. A Banda Quilombo do Rio das Rãs figura, nos espaços e tempos de realização e difusão do espetáculo, como porta-voz do povo quilombola que representa. Assemelha-se, desse ponto 
de vista, a outros grupos e movimentos musicais por meio dos quais os negros denunciam a opressão e o racismo. Munanga e Gomes $(2016,166)$ destacam o trabalho musical desenvolvido pelos grupos de rap, movimentos de organização e intervenção social que compreendem a articulação de várias linguagens artísticas e a realização de atividades comunitárias por jovens negros de periferia de grandes cidades. Do mesmo modo, ao cantar histórias de seu povo e propor transformações, por meio de vozes e corpos, a Banda Quilombo do Rio das Rãs aproxima-se dos múltiplos movimentos de resistência negra operacionalizados pela arte.

No interior do quilombo, como fora dele, o processo de autorreconhecimento e o engajamento em lutas fundamentadas na admissão de que há desigualdades das relações étnico-raciais demandam a aproximação dos jovens com tradições ancestrais. Ao cantar e dançar de acordo com o que se compreende como parte da história e cultura africana e afrobrasileira, em associação com outras referências culturais do passado e do presente, a Banda Quilombo do Rio das Rãs vivencia uma performance genuína, fruto das expectativas do idealizador da banda e do espetáculo, das memórias e dos saberes vivenciados pela comunidade e, em especial, dos jovens integrantes do grupo musical. O produto midiático comporta, desse modo, uma dimensão autoral e biográfica, reforçada pela inclusão, no vídeo, de depoimentos do Professor Zezinho, mas, ao mesmo tempo, promove o reconhecimento, para além da comunidade de origem, de múltiplos talentos, que cantam, tocam, dançam ou atuam nos bastidores, na produção do espetáculo. De alguma maneira, todos esses sujeitos estão envolvidos no debate proposto pelas letras das canções, pelo trabalho vocal, pela performance, centrados na história e cultura do seu povo.

Os sujeitos performativos da Banda Quilombo do Rio das Rãs se afirmam na condição de herdeiros daqueles que implantaram as primeiras formas de vida comunitária no território do Rio das Rãs e partilham saberes adquiridos nas experiências cotidianas. Cultivam a expectativa de que suas vozes e corpos, carregados de simbolismo e conhecimentos, vão chegar ao outro. Ao emergir no cenário artístico, cultural e político da Região Oeste do Estado da Bahia, as vozes do quilombo contribuem para a edificação de uma nova interpretação da trajetória do povo negro quilombola, ao negar os estereótipos a ele imputados, de incapacidade, incompetência e inabilidade. A banda é uma janela de acesso a esse conhecimento sobre os sujeitos quilombolas. Com a gravação e distribuição do DVD, esse conhecimento avança para novos espaços físicos e sociais. Os espectadores da apresentação em praça pública e todos aqueles que têm acesso às mídias digitais são incorporados, assim, a um processo de troca de saberes que pode contribuir para a desconstrução de estereótipos e para um novo modo de apreensão da história dos negros do Brasil.

Ainda que tardiamente, após um longo processo de recuperação e ressignificação da história e cultura negra, espectadores são mobilizados pela ideia de que a cultura negra e quilombola é fruto da criatividade e do trabalho de sujeitos emancipados e em luta permanente. Ao longo de mais de 500 anos, como destacam Munanga e Gomes (2016, 139), homens e mulheres negros tiveram que forjar formas de sobrevivência, inventar maneiras de lidar com o corpo e lançar mão de variadas formas de expressão para resistir à opressão e à discriminação. Inicialmente performavam em seus redutos, onde a maioria espectadora era constituída por sujeitos também negros, frente aos quais protagonizavam as (re)apresentações da história coletiva e serviam de fonte de inspiração para outros. Agora, no contexto da cultura-mundo (Lipovetsky e Serroy 2011, 149), emergem forças positivas capazes de reduzir ou mesmo anular os males que o mundo e, também, a própria cultura produzem. É nesse novo tempo que discursos, gestos, movimentos, caracteres linguísticos e elementos propriamente musicais presentes no espetáculo e no vídeo da Banda Quilombo do Rio das Rãs 
apontam para a possibilidade de afirmação de saberes que tomam a voz e a corporeidade negra como forças de mobilização. O reconhecimento desses saberes, de acordo com o que propõe Gomes (2017, 92), possibilita o estabelecimento de novos tipos de relações, suscita o aparecimento de novas linguagens e está na origem de uma ética fundada em uma nova ecologia de saberes relacionados ao corpo e à estética negra, fundamentais à autoaceitação do negro e à sua inclusão social.

\section{Considerações finais}

A noção de performance designa o objeto da apreensão sensível inicial e totalizante do real, o qual está amparado pela diferenciação sensorial e pela posse cognitiva. A performance se emoldura no tempo do espetáculo, quando o enunciado é recebido e apropriado pelo público. Zumthor $(2014,79)$ afirma que os sentidos se alinham ao conhecimento e por ele são utilizados na cadeia epistemológica sensação-percepçãoconhecimento-domínio do mundo. Esse princípio orienta as reflexões finais desse trabalho, sobre a participação do público no espetáculo performático, tendo como exemplo o trabalho da Banda Quilombo do Rio das Rãs. Em silêncio, inertes ou somando-se às vozes e movimentos dos membros da banda, os jovens que participam do espetáculo durante a apresentação ao vivo ou na condição de espectador do vídeo vivenciam novas experiências. Novos conhecimentos são ativados e a esse outro a quem falam os idealizadores e realizadores da performance é ofertada a possibilidade de rever preconceitos e estereótipos sobre o corpo negro emancipado e sobre as condições de existência dos povos quilombolas.

O trabalho da Banda Quilombo do Rio das Rãs filia-se à perspectiva de que a emancipação do indivíduo negro e a transformação social e cultural que poderia garantir novas experiências de cidadania tem por pressuposto o envolvimento em ações da comunidade negra organizada (Gomes 2017, 49). Mas essas ações envolvem tensões e contradições. O modo como indivíduos e grupos representam o mundo e elaboram os conhecimentos são dessemelhantes de acordo com a história de cada sujeito e de suas referências coletivas.

Os sujeitos que compõem a Banda Quilombo do Rio das Rãs tomam a música e a performance como estratégias para pôr em evidência e atribuir sentidos às histórias que elegem como adequadas aos propósitos de reforço aos processos identitários e engajamento de novos indivíduos na luta de resistência e por conquistas sociais. A produção do espetáculo, pensado a partir desses propósitos, exigiu uma logística de preparação que não pode ser desconsiderada. De acordo com Zumthor (2014, 45-46), os processos e as pulsões são elementos constitutivos dos atos performativos e a reflexão sobre os acontecimentos que antecedem a realização desses atos é fundamental à análise dos sentidos que lhe são intrínsecos. Ou seja, a performance não pode ser distanciada das razões e das ações que podem auxiliar o seu entendimento. Em uma situação específica de comunicação, essas motivações e ações têm o poder de modificar as percepções sobre as tradições e os conhecimentos postos em evidência.

Ainda que a recepção não ocorra no espaço e no instante da performance, como é o caso dos espectadores do DVD da Banda Quilombo do Rio das Rãs que só tiveram acesso ao espetáculo anos após a sua realização, a percepção é garantida pela eficiência de transmissão de som e imagem, eficiência que está em estreita correlação com o trabalho de edição e com o aproveitamento dos recursos tecnológicos disponíveis. A produção de sentidos é potencializada e modificada pela associação entre a linguagem musical a outros recursos, como depoimentos sobre a história das músicas, da banda e do grupo de origem. Enfim, é preciso 
considerar que a movimentação comunicacional, nas diversas etapas de realização e difusão do espetáculo, organiza-se no espaço social e é mediada por práticas educativas, políticas e, mesmo, performativas, que extrapolam as intenções e o tempo de realização. Os movimentos de resistência negra, a Igreja, o Estado, as escolas (agentes escolares, professores e alunos), assim como as universidades, têm o seu papel nesse processo de reconhecimento de saberes próprios às comunidades quilombolas e de projeção de suas formas de expressão, aqui exemplificadas pelo espetáculo performático da Banda Quilombo do Rio das Rãs.

\section{Referências}

Banda Quilombo do Rio das Rãs. 2009. Bom Jesus da Lapa: Secretaria de Cultura do Estado da Bahia. 1 DVD (1h33 min.).

Bourdieu, Pierre. 1989. O Poder simbólico. Rio de Janeiro: Bertrand Brasil.

Doria, Siglia Z. e Carvalho, José J. de. 1996. “A experiência comunitária." In O Quilombo do Rio das Rãs: histórias, tradições, lutas, org. por José J. Carvalho, Siglia Z. Doria e Adolfo N. de Oliveira Jr, 115-153. Salvador: EDUFBA.

Dutra, Nivaldo O. 2007. Liberdade é reconhecer que estamos no que é nosso: comunidades negras do Rio das Rãs e da Brasileira - BA (1982-2004). Dissertação (Mestrado em História) - Pontifícia Universidade Católica de São Paulo, São Paulo.

Gomes, Nilma L. 2017. O Movimento negro educador: saberes construídos nas lutas por emancipação. Petrópolis: Vozes.

Lipovetsky, Gilles e Serroy, Jean. 2011. A cultura-mundo: resposta a uma sociedade desorientada. São Paulo: Companhia das letras.

Martín-Barbero, Jesús. 1997. Dos meios às mediações. Comunicação, cultura e hegemonia. Rio de. Janeiro: UFRJ

Munanga, Kabengele e Gomes, Nilma L. 2016. O negro no Brasil de hoje. São Paulo: Global.

Oliveira, Íris M. de e Paiva, Pe. Antônio M. de. s./d. História da PJMP. Disponível em: http://www.pjmp.org/historia. Acesso em: 9 set. 2020.

Oliveira Jr, Adolfo N. de. 1996. "Reflexão antropológica e prática pericial." In O quilombo do Rio das Rãs: Histórias, tradições, lutas, org. por José J. de Carvalho, Siglia Z. Doria e Adolfo N. de Oliveira Jr, 152175. Salvador: EDUFBA.

Schaeber, Petra. 1997. "Música negra nos tempos de globalização: produção musical e management da identidade étnica - o caso do Olodum." In Ritmos em trânsito: sócio-antropologia da música baiana, org. por Livio Sansone e Jocélio T. dos Santos. São Paulo: Dynamis.

Zumthor, Paul. 2014. Performance, recepção, leitura. São Paulo: Cosac Naify. 